\title{
Performance Assessment of the Rehabilitated Mudor Sewage Treatment Plant at James Town Accra-Ghana
}

\author{
Issahaku Ahmed ${ }^{1}$, Dennis Ofori-Amanfo', Esi Awuah ${ }^{2}$, Florence Cobbold1 \\ ${ }^{1}$ Sewerage Systems Ghana Ltd., Accra, Ghana \\ ${ }^{2}$ Department of Civil Engineering, Kwame Nkrumah University of Science and Technology, Kumasi, Ghana \\ Email: ^eagleskertoozer@yahoo.co.uk, oblon13@hotmail.com, esiawuahrt@gmail.com, fcobbold@hotmail.com
}

How to cite this paper: Ahmed, I., Ofori-Amanfo, D., Awuah, E. and Cobbold, F. (2018) Performance Assessment of the Rehabilitated Mudor Sewage Treatment Plant at James Town Accra-Ghana. Journal of Water Resource and Protection, 10, 725-739.

https://doi.org/10.4236/jwarp.2018.108041

Received: May 23, 2018

Accepted: July 30, 2018

Published: August 2, 2018

Copyright $\odot 2018$ by authors and Scientific Research Publishing Inc. This work is licensed under the Creative Commons Attribution International License (CC BY 4.0).

http://creativecommons.org/licenses/by/4.0/

(c) (i) Open Access

\begin{abstract}
The Rehabilitated Mudor sewage treatment plant at James Town was monitored over a period of 4 months (October 2017 to January 2018). This study analyzed the physical, chemical and biological parameters of the raw sewage and the treated effluent from the plant. The result indicates that the total removal efficiencies were $98.8 \%, 91.2 \%, 62.8 \%, 28.6 \%, 81.7 \%, 43.6 \%, 82.5 \%$ and 99.6\% for BOD, COD, TSS, Nitrate-Nitrogen, Phosphate-Phosphorus, Ammonia-nitrogen, Sulphate and faecal coliform respectively. More than 13 parameters needed to be met according to the Ghana Environmental Protection Agency (EPA) guideline were satisfactorily met whiles ammonia, total suspended solids and phosphate were slightly out of range. From the results obtained, the overall performance of the rehabilitated plant was satisfactory and has seen some improvement with respect to the former recorded performance of the plant. With monitoring operation parameters for waste water plants discharge guidelines becoming stringent over the past years, it could be said that management of the Mudor rehabilitated treatment plant is on the right cause with full scale operation of the plant barely less than a year. Increase in the process steps through rehabilitation resulted in several significant improvements in effluent quality parameters.
\end{abstract}

\section{Keywords}

Mudor WWTP, Rehabilitation, Physico-Chemical Parameters, Performance Assessment

\section{Introduction}

Environmental sanitation is an essential factor contributing to the health, prod- 
uctivity and welfare of the people of Ghana. It is identified in Ghana's programme of economic and social development set out in "VISION 2020" as a key element underlying health and human development [1]. Over the years there has been a lack of political will in Ghana to implement basic sanitation and this is reflected in the amount of resource allocated for waste water management [2]. Part of this problem is attributed to the upsurge in urban population in Ghana which is expected to be increasing over the coming years, resulting in environmental deterioration and frequent outbreak of water-borne diseases. However, progress in terms of sanitation is gaining some needed attention with the introduction of the sanitation ministry. It has been projected that in the near future, the number of treatment plants such as the three treatment plants operated by Sewerage Systems Ghana Limited, may gradually increase and a large demand for information on appropriate procedures and technologies has to be developed. With the introduction of the new Lavender Hill Faecal treatment plant coupled with the back-online rehabilitated Mudor waste water treatment plant in 2017, it could be said that there has been a significant reduction in the outbreak of water-borne diseases such as cholera and other water-borne related diseases. Establishment of such facilities in all regions in Ghana could minimize environmental problems and health risks.

Many small-scale municipal treatment plants are established in municipalities but a great number of them are not working at all or are not working with high performance [3]. The Mudor sewage treatment plant collects domestic sewage from Ministries, Osu-Labone, High Street, parts of Dansoman area, Accra Central and Korle $\mathrm{Bu}$ all in the Greater Accra Region of Ghana. Most of these areas have pump stations which pumps waste water into the plant, generating a discharge flow of 16,000 to $18,000 \mathrm{~m}^{3}$ per day. Research has indicated that liquid waste containing Faecal matter consist of high foreign material load [4]. The loads are removed from waste water by screening and the grit removal chamber, this treatment process is termed as the primary treatment stage. Other processes of the plant includes; sludge thickeners, aerobic fixed growth reactors (trickling filter), which was formally two but upgraded to three, Final Settling Tanks and sludge drying beds. The flow from the above mentioned sewered areas are discharged into the plant inlet where foreign material load of the sewage is screened. The screened waste water is discharged into a receptacle where it is lifted to the fine screen chamber, where fine particles of sand are trapped. The grit and screenings end up in a waste chute which is cleared into a skip for disposal. The effluent from the grit channel is diverted to primary distribution boxes. The primary distribution boxes ensure an evenly proportion flow to the biological reactors. Each channel from the primary distribution boxes feed secondary and tertiary distribution boxes. The tertiary distribution boxes connect directly to the down pipes that convey waste water to the bottom of the UASB reactors. Anaerobic by-products, including methane $\left(\mathrm{CH}_{4}\right)$, carbon dioxide $\left(\mathrm{CO}_{2}\right)$ and hydrogen sulphide $\left(\mathrm{H}_{2} \mathrm{~S}\right)$ are generated. The gas produced from the 
reactors is collected into gas collector hoods to prevent release of biogas into the environment. The effluent from the UASB reactor flows by gravity to the trickling filters. Effluent from the trickling filters then flows to the Final settling tanks (FST) where fine solids are allowed to settle and further organic reduction is achieved before effluent flows to the final sampling chamber. Sludge collected at the FST basin is pumped back into the sludge thickeners. The drying beds receive sludge pumped from the sludge thickeners where liquid drainage is affected through sand filters and a system of under-drain.

The Mudor waste water treatment plant uses the Up-flow Anaerobic Sludge Blanket (UASB) reactor as a unit for sewage treatment (Figure 1) and research has indicated that about $65 \%$ to $80 \%$ of organic matter removal efficiency can be obtained in conventional UASB reactors even with short retention time of about 4 to 6 hours in hot climate areas [2]. The process of the rehabilitation of the Mudor WWTP saw an extension in volume of treatment per day, extension of the trickling filters, and adoption of the activated sludge. The rehabilitation process consists of operational steps where microorganisms are grown with consequential degradation of particulate and dissolved liquid wastes. The

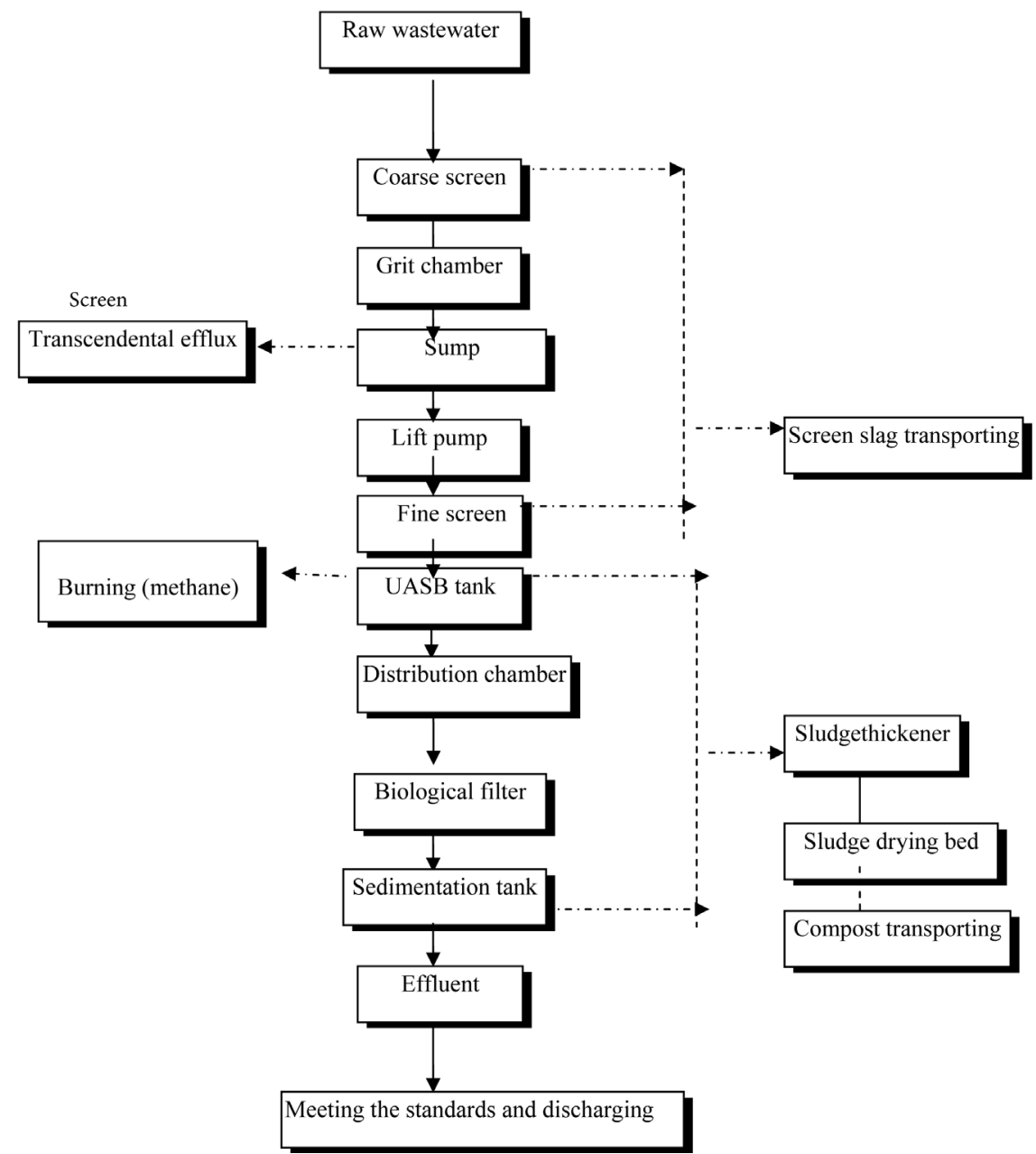

Figure 1. Process flow diagram of the Mudor waste water treatment plant. 
microbial solids produced in these reactors are separated by process of sedimentation with most portion of the settled solids recycled back to the bioreactors so as to have high solids concentrations as well as rates of reaction (Figure 1). Research works have also indicated that the distribution of the functions adopted in the rehabilitated operational process can vary within activated sludge due to seasonal flow rates variations, seasonal variability of biomass density and aeration conditions [5] [6]. Such variations have the potential to result in an operational risk impact on the plant and improper operation of WWTP may lead to discharge of contaminated effluents leading to negative consequences in relation to environmental and public health [7]. Research has also indicated that in developing countries 1.8 million people, mostly children, die every year as a result of water-related diseases [8] [9] [10]. Research has also outlined the major contribution to chemical contamination to have originated from domestic and industrial waste water discharges containing both organic and inorganic contaminants that negatively impact water quality [11] [12] [13]. Water quality is affected by a wide range of natural and anthropogenic influences [14]. Natural processes (hydrological, physical, chemical and biological) may affect the characteristics and concentration of chemical elements and compounds in freshwater. The works of Dione [14] also outlines factors such as human-induced point and nonpoint pollution sources being key contributors to anthropogenic impacts that affect water quality. These factors make it imperative for the performance of WWTP be monitored on a regular basis [6].

In this context as also highlighted by the works of Belhaj [7], this study therefore seeks to determine the overall performance of the rehabilitated Mudor waste water treatment plant at James Town, Accra; with specific objective of assessing the day to day operations and to determine the nutrient, organic and pathogenic removal efficiency of the rehabilitated plant. Exhaustive data from a previous research work [2] conducted on the plant before its rehabilitation was comparatively treated to ascertain the plant performance based on past observations of certain key product quality parameters. These results would not only give the managers of the plant a fair view of the effectiveness of the rehabilitation and operational management will and capabilities but also simplify design decisions to optimize pollutant removal from urban waste waters.

The plant was monitored by measuring the characteristics of the process parameters of both influent and effluents to assess the overall performance of the plant for sixteen weeks (four months). This paper presents an overview of the rehabilitated Mudor waste water treatment plant in the Greater Accra region of Ghana.

\section{Methodology}

\subsection{Study Area}

The study was conducted at the rehabilitated Mudor waste water treatment plant located in the greater Accra region of Ghana (Figure 2); a designated area 


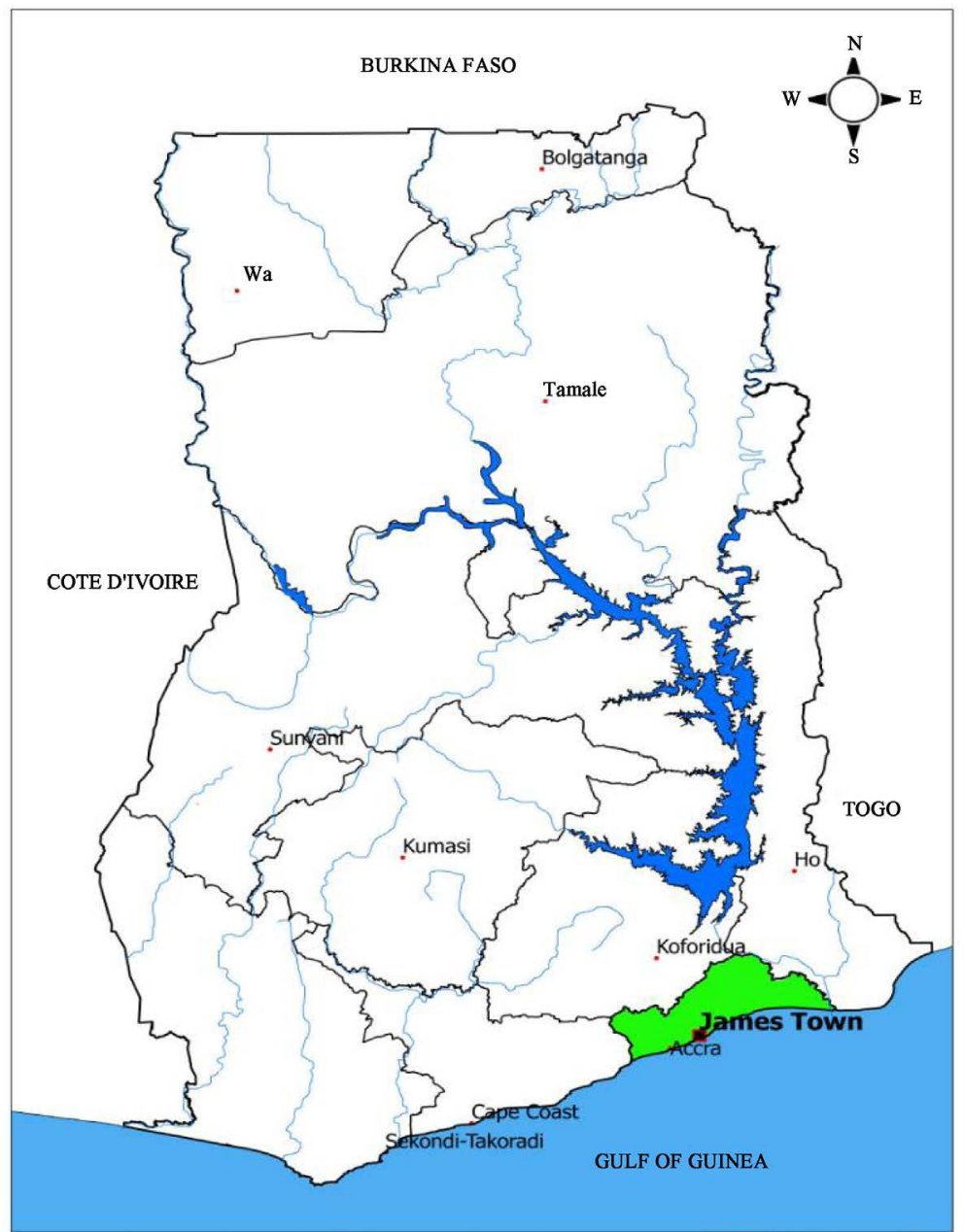

Figure 2. Located site of the Study Area, James Town-Accra Ghana.

by the Accra Metropolitan Area (AMA) as a sanitary site. The Mudor waste water was constructed by the Taysec construction and was commission in the year 2000. The plant was shut down after some few years of operations due to maintenance issues and lack of financial commitments and rehabilitated into operation in the year 2017. The total land area for the plant is 6.3 acres, situated less than 20 meters east-ward from the Korle-Lagoon.

\subsection{Sampling and Analysis Methods}

Composite samples were made from each process unit daily. For each day, the composite sample was made from hourly sampling of the effluent from each of the process units. Each of the daily composited sample contains 24 different number of samples (1 sample for each hour in a day). For each hourly sampling, about $200 \mathrm{ml}$ of the respective unit effluent was taken and transferred into the controlled composite sample container. This was repeated for a period of sixteen weeks and a total of about 120 composite samples were used for the laboratory analysis. The laboratory studies were conducted at the Lavender Hill Faecal Treatment Plant Lab located on the same enclave of the Mudor treatment plant. 
Sampled (composite) waste water for the present research was selected from the various treatment units of the Mudor waste water treatment plant and process parameters analyzed, in terms of their COD which was measured after potassium dichromate digestion with $\mathrm{HACH}$ instrument (DR1900), $\mathrm{BOD}_{5}$ test method APHA 5210, Total Suspended Solids [15], pH, EC and Dissolved Oxygen were measured using multi parameter $\mathrm{pH}$ meter (HQ40D LDO10101), faecal coliform, the nutrients (total nitrogen, ammonia nitrogen, phosphate, sulphate, nitrate) were determined using the HACH DR1900 in line with the APHA methods [15]. Details of the instrumentation make and models are highlighted in the electronic supporting document.

\subsection{Qualitative Analysis of Process Influent and Effluent}

The influents and effluents of the plant processes were analyzed for $\mathrm{PH}$, dissolved oxygen, turbidity, Chemical Oxygen Demand (COD), Total Solids (TS), Biochemical Oxygen Demand (BOD), Nitrate-Nitrogen $\left(\mathrm{NO}_{3}-\mathrm{N}\right)$, Ammonia-Nitrogen $\left(\mathrm{NH}_{3}-\mathrm{N}\right)$, Phosphate-Phosphorus $\left(\mathrm{PO}_{4}-\mathrm{P}\right)$ and Faecal Coliform $(\mathrm{FC})$

\section{Results and Discussions}

\subsection{Hydrogen-Ion Concentration (pH)}

Most microbial life occurs within narrow $\mathrm{pH}$ range, it is typically evidence to be 6 - 9. Biological treatment of waste water is of great concern in relation to the hydrogen ion concentration. Influent waste water with extremely high or low $\mathrm{pH}$ values are difficult/impossible to treat with biological means. Treatment plant effluent water with High or low $\mathrm{pH}$ ranges may affect the natural waters in the recipient as well [16] [17]. pH values recorded ranged from 6.74 - 7.26 (Table 2), for the composite sample of the raw sewage. The analysis showed that the $\mathrm{pH}$ of the influent has a very narrow variety in both the acidic and alkaline range; the acidic nature of the influent could have been as a results of discharge from acid based compounds/chemicals, from SME/industries, homes that are linked to the treatment plant or discharged into open drains connecting into the treatment facility. The alkaline range of influent water, this is probably because of discharge from homes using detergents, soaps, creams etc. The close $\mathrm{pH}$ range values recorded indicates a less retention time for treatment as long as $\mathrm{pH}$ is not so severe to completely stop the bacterial metabolism generating $\mathrm{CO}_{2}$ (acidic gas) as by-product. $\mathrm{pH}$ values of effluent from the UASB reactors ranged from 6.77 7.82 , maintaining almost a neutral range. $\mathrm{PH}$ values recorded ranges from 7.71 $8.09,7.62-8.32$ and $7.88-8.22$ for the composite of effluent from the trickling filter, the final settling tanks and the final effluent discharged. Unlike the initial works that was done [2] which reported $\mathrm{pH}$ values of influent being higher than the final effluent even though it is within the range of 6 - 9. It was seen in this work that measured $\mathrm{pH}$ values were consistently increased by between 0.3 and 0.9 units giving relatively stable daily, weekly and monthly average $\mathrm{pH}$ effluent 
between 7.94 and 8.14 (Table 2). This observation is consistent with the works of Belhaj and coworkers [7].

\subsection{Temperature $\left({ }^{\circ} \mathrm{C}\right)$}

In order to maintain the optimal performance of full scale UASB plant or activated sludge plant, Solid Retention Time (SRT) should be changed with temperature in a dynamic way. The average temperature ranged recorded was $25.38^{\circ} \mathrm{C}$, $24.06^{\circ} \mathrm{C}, 23.44^{\circ} \mathrm{C}, 23.6^{\circ} \mathrm{C}$ and $24.49^{\circ} \mathrm{C}$ indicative of influent, effluent from the UASB reactors, effluent from the tricking filter, final settling tank effluent and the final effluent respectively, the plant can be classified as being operating at low temperature range of $20^{\circ} \mathrm{C}-23^{\circ} \mathrm{C}$ and or moderately high temperature thus less than $28^{\circ} \mathrm{C}$. This temperature range phenomenon is consistent with the previous work [2]. $\mathrm{BOD}_{5}$ and nitrification are optimally achieved at given SRT with respective variation of days over maximum and low temperature ranges. Research work has indicated that high water temperature decreases the solubility gas and increases the photosynthetic rate of algae and aquatic plants. This phenomenon has the potential of leading to increased plant growth and algal blooms [18] [19]. It is also alerted that a general change in water temperature can affect the general health of aquatic organisms as organisms become stressed in too hot or too cold temperatures while their resistance to diseases and pollutants becomes lowered [18] [20]. The values recorded for each treatment units falls within the Ghana Environmental Protection Agency (EPA) permissible guideline and it is also in consonance with the work of Alabaster and Lloyd [21] which reported that natural inland waters in the tropics have temperature ranging between $25^{\circ} \mathrm{C}$ and $35^{\circ} \mathrm{C}$.

\subsection{Electrical Conductivity (EC)}

The EC of water, like TDS, is an indicator of total salt content of the water [22]. Electrical conductivity values recorded ranged from 1333 - $1879 \mu \mathrm{S} / \mathrm{Cm}, 100$ $2084 \mu \mathrm{S} / \mathrm{Cm}, 1409$ - $1984 \mu \mathrm{S} / \mathrm{Cm}, 1213$ - $2084 \mu \mathrm{S} / \mathrm{Cm}$ and $100-2012 \mu \mathrm{S} / \mathrm{Cm}$ indicating raw sewage (influent), the effluent from the UASB reactors, effluent from the Trickling filter, the final effluent settling tank and the final effluent respectively. The value recorded for the final effluent met EPA Ghana guideline for waste water discharge of $1500 \mu \mathrm{S} / \mathrm{Cm}$. The previously reported work did not highlight the conductivity status of the influent-effluent characteristics. Even though the EC met the guideline, the effluent water is highly saline due to the level of the conductivity.

\subsection{Turbidity and Total Suspended Solids}

Turbidity values recorded ranged from 391 - 858 NTU and 12 - 39 NTU for the composite of influent and effluent respectively. High turbidity range is as a result of suspended solids in the form of organic constituents in the waste water. High turbidity values were significantly reduced throughout the various process stag- 
es, getting effluent values to be within the acceptable value of EPA guideline of 75 NTU. The final effluent being discharged yielded an average of 20.71 NTU (Table 2), the obtained value shows significant improvement as compared to Awuah \& Abrokwa research [2] conducted in 2008 with recorded final average effluent value of 122 NTU (Table 1).

Reduction in turbidity values is as a result of degrading of organic by microbial organisms in the waste water. Total solids values recorded ranged from 100 $1300 \mathrm{mg} / \mathrm{l}$ and 100 - $400 \mathrm{mg} / \mathrm{l}$ for the composite of influent and final effluent respectively. The overall removal efficiency of the plant from the influent to the final effluent was $96.6 \%$ (Table 2) and this was also seen to be higher than that reported in the previous work [2] (Table 1).

\subsection{Colour}

Average colour recorded was 191.3 TCU for the final effluent discharge (Table 2). The value obtained falls within the EPA acceptable limit of 200 TCU guidelines. Previous research conducted [2] did not report on such parameter. The initial average influent colour value recorded was 5389 TCU, colour being organic material that has dissolved into water, it could be said that most dissolved organic materials were reduced significantly by the various treatment units of the plant.

\subsection{Dissolved Oxygen (D0)}

Dissolved oxygen values ranged from $0.00-0.28 \mathrm{mg} / \mathrm{l}$ and $1.02-3.07 \mathrm{mg} / \mathrm{l}$ for the composite of influent and effluent respectively. UASB reactors recorded

Table 1. Characteristics of sewage at the different stages and comparison of effluent with EPA Ghana 2000, guidelines.

\begin{tabular}{|c|c|c|c|c|c|c|c|}
\hline Parameter & $\begin{array}{l}\text { Final influent } \\
\text { mean values }\end{array}$ & $\begin{array}{l}\text { UASB reactor } \\
\text { effluent }\end{array}$ & $\begin{array}{c}\text { Trickling filter } \\
\text { effluent }\end{array}$ & $\begin{array}{c}\text { Final settling tank } \\
\text { effluent }\end{array}$ & $\begin{array}{c}\text { Final } \\
\text { effluent mean } \\
\text { values }\end{array}$ & $\begin{array}{c}\text { Total } \\
\text { efficiency of } \\
\text { the plant (\%) }\end{array}$ & $\begin{array}{c}\text { EPA Ghana } \\
\text { guidelines, } \\
2000\end{array}$ \\
\hline $\mathrm{pH}$ & $8.96 \pm 0.98$ & $6.7 \pm 0.19$ & $7.51 \pm 0.13$ & $7.5 \pm 0.14$ & $7.45 \pm 0.14$ & - & $6-9$ \\
\hline Dissolved oxygen (mg/l) & $0.46 \pm 0.26$ & $0.58 \pm 0.21$ & $5.26 \pm 0.32$ & $4.24 \pm 1.08$ & $4.24 \pm 1.08$ & - & - \\
\hline Turbidity (NTU) & $1923 \pm 646$ & $265 \pm 44$ & $207 \pm 62$ & $125 \pm 50$ & $122 \pm 5 \mathrm{e} 0.27$ & - & 75 \\
\hline Total solids (mg/l) & $3200 \pm 2571$ & $1011 \pm 130$ & $1038 \pm 135$ & $966 \pm 94$ & $958 \pm 93.78$ & 68.8 & - \\
\hline $\mathrm{COD}(\mathrm{mg} / \mathrm{l})$ & $3173 \pm 1528$ & $340 \pm 74$ & $310 \pm 69$ & $145 \pm 21$ & $146 \pm 20.62$ & 94.4 & 250 \\
\hline $\mathrm{BOD}(\mathrm{mg} / \mathrm{l})$ & $1206 \pm 397$ & $73 \pm 16.2$ & $42 \pm 114$ & $23 \pm 5.7$ & $23 \pm 5.74$ & 98.1 & 50 \\
\hline $\begin{array}{c}\text { Ammonia-nitrogen } \\
(\mathrm{mg} / \mathrm{l})\end{array}$ & $4.3 \pm 1.73$ & $19.6 \pm 2.4$ & $7.9 \pm 1.4$ & $2.6 \pm 0.7$ & $2.6 \pm 0.68$ & 39.5 & 1.5 \\
\hline Nitrate-nitrogen $(\mathrm{mg} / \mathrm{l})$ & $29 \pm 2.82$ & $6.0 \pm 1.6$ & $16.6 \pm 2.5$ & $22.1 \pm 0.83$ & $22.1 \pm 0.83$ & 23.8 & 0.1 \\
\hline TKN (mg/l) & $52.6 \pm 4.11$ & $93.1 \pm 6.5$ & $60.7 \pm 2.25$ & $43.1 \pm 1.2$ & $43.1 \pm 1.15$ & 17.4 & - \\
\hline Phosphate-phosphorus & $2.31 \pm 0.14$ & $1.03 \pm 0.17$ & $1.47 \pm 0.53$ & $0.5 \pm 0.14$ & $0.5 \pm 0.14$ & 78.3 & 2 \\
\hline $\begin{array}{c}\text { Faecal } \\
\text { coliform }(\text { No./100ml })\end{array}$ & $\begin{array}{c}9.2 \times 10^{5} \pm \\
1.1 \times 10^{5}\end{array}$ & $\begin{array}{c}2.0 \times 10^{5} \pm \\
4.9 \times 10^{4}\end{array}$ & $\begin{array}{c}1.2 \times 10^{5} \pm \\
1.8 \times 10^{4}\end{array}$ & $\begin{array}{c}2.15 \times 10^{2} \pm \\
16.31\end{array}$ & $\begin{array}{c}2.16 \times 10^{2} \pm \\
16.31\end{array}$ & 99.9 & $10-100$ \\
\hline
\end{tabular}

Source: Awuah and Abrokwa, 2008 [2]. 
Table 2. Characteristics of sewage at the different stages and comparison of effluent with EPA Ghana guidelines-(Observation time: $6 \mathrm{am}-5 \mathrm{am})$.

\begin{tabular}{|c|c|c|c|c|c|c|c|}
\hline Parameter & $\begin{array}{c}\text { Influent } \\
\text { (Raw sewage) } \\
\text { mean values }\end{array}$ & $\begin{array}{c}\text { UASB reactor } \\
\text { effluent }\end{array}$ & $\begin{array}{c}\text { Trickling filter } \\
\text { effluent }\end{array}$ & $\begin{array}{l}\text { Final settling } \\
\text { tank effluent }\end{array}$ & $\begin{array}{l}\text { Final effluent } \\
\text { mean values }\end{array}$ & $\begin{array}{l}\text { Total } \\
\text { efficiency of } \\
\text { the plant (\%) }\end{array}$ & $\begin{array}{l}\text { EPA Ghana } \\
\text { guidelines, } \\
2000\end{array}$ \\
\hline $\mathrm{pH}$ & $7.00 \pm 0.26$ & $7.17 \pm 0.34$ & $7.93 \pm 0.92$ & $7.96 \pm 0.15$ & $8.04 \pm 0.10$ & - & $6-9$ \\
\hline Temperature $\left({ }^{\circ} \mathrm{C}\right)$ & $25.38 \pm 1.89$ & $24.06 \pm 2.58$ & $23.44 \pm 2.28$ & $23.6 \pm 2.46$ & $24.49 \pm 1.99$ & - & $<30$ \\
\hline Conductivity $(\mu \mathrm{S} / \mathrm{Cm})$ & $1591 \pm 176.7$ & $1977 \pm 280$ & $1729 \pm 234$ & $1655 \pm 319$ & $1383 \pm 428$ & - & 1500 \\
\hline $\begin{array}{l}\text { Dissolved oxygen } \\
(\mathrm{mg} / \mathrm{l})\end{array}$ & $0.05 \pm 0.08$ & $0.25 \pm 0.26$ & $1.49 \pm 0.72$ & $1.62 \pm 0.46$ & $1.76 \pm 0.70$ & - & - \\
\hline Turbidity (NTU) & $607.3 \pm 143$ & $122.9 \pm 21.73$ & $60.11 \pm 30$ & $19.43 \pm 5.9$ & $20.71 \pm 7.0$ & 96.6 & 75 \\
\hline Total solids (mg/l) & $740.4 \pm 313$ & $340 \pm 140$ & $314.3 \pm 128$ & $300 \pm 133$ & $260.3 \pm 101$ & 64.8 & 50 \\
\hline $\mathrm{COD}(\mathrm{mg} / \mathrm{l})$ & $1483 \pm 750$ & $252 \pm 81$ & $246 \pm 116$ & $129.3 \pm 56$ & $129.9 \pm 53$ & 91.2 & 250 \\
\hline Oil and grease $(\mathrm{mg} / \mathrm{l})$ & $19.62 \pm 0.7$ & $9.84 \pm 0.7$ & $3.38 \pm 0.4$ & $2 . .09 \pm 3.5$ & $3.77 \pm 0.3$ & $0.54 \pm 0.5$ & 5 \\
\hline Colour (TCU) & $5389 \pm 307$ & $2496 \pm 20$ & $252.1 \pm 47$ & $193 \pm 11.16$ & $162.3 \pm 13.4$ & 97.0 & 200 \\
\hline $\begin{array}{l}\text { Ammonia-nitrogen } \\
(\mathrm{mg} / \mathrm{l})\end{array}$ & $66.88 \pm 4.10$ & $307.9 \pm 17.19$ & $121.7 \pm 21.68$ & $39.57 \pm 3.94$ & $37.73 \pm 4.14$ & 43.6 & 1 \\
\hline $\begin{array}{l}\text { Nitrate-nitrogen } \\
(\mathrm{mg} / \mathrm{l})\end{array}$ & $354.6 \pm 49.53$ & $70.65 \pm 1.08$ & $195 \pm 10.11$ & $253 \pm 31.81$ & $253.2 \pm 35$ & 28.6 & 50 \\
\hline Sulphate (mg/l) & $375.5 \pm 53.4$ & $112.7 \pm 29.2$ & $79.57 \pm 6.8$ & $69.13 \pm 6.9$ & $65.53 \pm 5.45$ & 82.5 & 200 \\
\hline Phosphate-phosphorus & $36.83 \pm 4.0$ & $7.17 \pm 0.34$ & $22.42 \pm 0.12$ & $8.18 \pm 2.52$ & $6.71 \pm 0.63$ & 81.7 & 2 \\
\hline $\begin{array}{l}\text { Faecal coliform } \\
\text { MPN/100ml) }\end{array}$ & $\begin{array}{c}8.9 \times 10^{5} \pm \\
0.7 \times 10^{5}\end{array}$ & $\begin{array}{c}2.7 \times 10^{5} \pm \\
0.4 \times 10^{4}\end{array}$ & $\begin{array}{c}2.6 \times 10^{5} \pm \\
0.4 \times 10^{4}\end{array}$ & $\begin{array}{c}3.02 \times 10^{2} \pm \\
16.31\end{array}$ & $\begin{array}{c}3.78 \times 10^{2} \pm \\
16.31\end{array}$ & 99.6 & 400 \\
\hline
\end{tabular}

values ranging from $0-0.83 \mathrm{mg} / \mathrm{l}$ and $0.62-2.86 \mathrm{mg} / \mathrm{l}$ was recorded for the trickling filters. The analysis showed low DO values for the influent and this can be attributed to high microbial load in the influent waste water that has utilized maximum amount of the oxygen. The flow of waste water through sewered network could also result in the low DO values. Increased DO values in the UASB, trickling filters and the final effluent are as results of reduction in the microbial load in the waste water and the flow of effluents through open channels. High DO values recorded in the effluent is an indication of good effluent quality with respect to DO and can be discharged into the environment without causing any health implications. The observed trend with respect to this parameter is consistent with the previous work reported [2].

\subsection{Chemical Oxygen Demand (COD)}

Composite samples of influent (raw sewage) and effluent COD from the UASB recorded ranged from $760-3600 \mathrm{mg} / \mathrm{l}$ and $110-400 \mathrm{mg} / \mathrm{l}$ respectively. The influent samples showed high values of COD; influent and effluent values showed wide variance as a result of high efficiency of the UASB reactors in removing organic material from the waste water. The removal efficiency of the UASB reactors was $88.9 \%$ which is higher than the removal efficiency stated by Awuah 
\& Abrokwa [2] with stated COD removal efficiency of $86 \%$. This is a primary outcome of the activated sludge duo recycle that ensures maximum anaerobic sludge is actively present in the bioreactors. The trickling filters further reduced the COD concentrations, recording ranged figures of $80-400 \mathrm{mg} / \mathrm{l}$ with removal efficiency of $27.3 \%$. The final effluent value recorded ranged from $40-200 \mathrm{mg} / \mathrm{l}$ which indicates a removal efficiency of $50 \%$ for the final settling tanks. The final effluent values meet the EPA guideline and it is consistent with the work reported earlier [2]. Even though it meets the guideline, the overall removal efficiency of the plant was seen to be $91.2 \%$ (Table 2) which is lower than values recorded in the earlier work [2] as shown in Table 1 to be $94.4 \%$. The decrease in the efficiency is attributed to the relatively low COD values of the influent that was received coupled with high variations between the minimum and the maximum recorded values during the study.

\subsection{Biological Oxygen Demand (BOD)}

Values recorded for BOD were $1950 \mathrm{mg} / \mathrm{l}, 79 \mathrm{mg} / \mathrm{l}, 45 \mathrm{mg} / \mathrm{l}$ and $27 \mathrm{mg} / \mathrm{l}$ for the influent (raw sewage), UASB, Trickling filter and the final settling tank effluent respectively. The various treatment units of the plant significantly reduced the BOD concentrations. The final effluent quality is very much desirable as it falls within the EPA required regulation of $50 \mathrm{mg} / \mathrm{l}$ and this is consistent with the earlier work [2]. Even though, the obtained BOD values for the two research works meets the EPA guideline, the overall BOD removal efficiency of the plant in this work is $98.8 \%$ (Table 2) and is noted to be higher than values recorded by the previous work [2] which was stated to be $98.1 \%$ (Table 1 ).

\subsection{Phosphate-Phosphorus}

Taking note of Table 2, the average values recorded for phosphate were 36.8 $\mathrm{mg} / \mathrm{l}, 7.171 \mathrm{mg} / \mathrm{l}, 22.42 \mathrm{mg} / \mathrm{l}, 8.18$ and 0.20 for the raw sewage, UASB reactors effluent, trickling filters effluent, final settling tank effluent and final effluent respectively. The final effluent value does not meet EPA recommended effluent limits. Due to the rich nutrient recorded as phosphate, it would be a surrogate measure of available nutrient uptake if the effluent is to be use in irrigation in order to promote an integrated nutrient management approach in agriculture. This point of using it in irrigation was highlighted in the previous work as well. However, the current management of the plant are using part of the effluent to water the lawns within the plant premises. On the other hand, research work conducted by Nthlumbi [23] indicates that high phosphate can stimulate a rapid growth of photosynthetic algae and cyanobacteria resulting in eutrophication. Eutrophication also has the potential to increase treatment cost. It is not surprising that, work conducted by Akoto [24] shows that high level of phosphate in treated drinking water for a certain community in the suburb of Kumasi in Ghana has sewage as a potential source whiles Akpali [25] highlighted drains rich in detergents being the contributing factors of high phosphates. 


\subsection{Ammonia-Nitrogen}

Ammonia-nitrogen recorded mean values of $66.88 \mathrm{mg} / \mathrm{l}$ for the influent, 307.9 $\mathrm{mg} / \mathrm{l}$ for the UASB reactors effluent. It was observed that there was an increase in the monitored $\mathrm{NH}_{3}$-Nvalues for UASB reactors, this observation was noted in the previous work conducted [2]. It is being suspected that, the anaerobic conditions of the UASB reactors could have seen some form of nitrification in the process. Average values recorded in the Trickling filters, final settling tank and final effluent were; $121.7 \mathrm{mg} / \mathrm{l}, 39.57 \mathrm{mg} / \mathrm{l}$ and $37.73 \mathrm{mg} / \mathrm{l}$ respectively. It was revealed that the final average effluent value reduced by $43.6 \%$ but could not meet the EPA effluent discharge guidelines. This observation was consistent with the work reported earlier [2] (Table 1). Although concentrations recorded for ammonia exceeded the EPA guideline, the obtained efficiency of $43.6 \%$ (Table 2) was higher than what was recorded in the previous research work [2] (Table 1, Table 3).

\subsection{Sulphate}

Presence of Sulphate even in low concentrations has the potential to pose serious cathartic effect on humans. The adverse consequence of the presence of sulphate can also be mention on its ability to increase salinity and inhibits some advanced waste water treatment processes. Sulphate recorded mean values of $375.5 \mathrm{mg} / \mathrm{l}$ for the influent, $112.75 \mathrm{mg} / \mathrm{l}$ in the UASB reactor effluent. The removal efficiency for the UASB reactors was $70 \%$. Values recorded for other process parameters was, $79.57 \%, 69.13 \%$ and $65.53 \%$ for trickling filter effluent, final settling tanks effluent and final effluent respectively. The overall sulphate removal efficiency of the plant was $82.5 \%$. The final effluent discharge value falls within the recommended acceptable EPA limit of $200 \mathrm{mg} / \mathrm{l}$. The results obtained from the plant can be said to be very good. Previous literature on the plant [2] did not report on such findings (Table 1 , Table 3 ).

Considering all the nutrients monitored, the effluent had nitrate to be very high in concentration followed by sulphate in all the samples monitored overtime and the nutrient concentrations were found to be in the order: $\mathrm{PO}_{4}^{3-}<$ $\mathrm{NH}_{3}<\mathrm{SO}_{4}^{2-}<\mathrm{NO}_{3}^{-}$. This observed trend of nutrient in water where the anionic nutrients were found to be higher than ammonia is consistent with the work of Akoto [26] on treated drinking water except for phosphate that was lower.

\subsection{Faecal Coliform}

The use of Faecal indicator organisms (FIO) have been extensively used to evaluate water quality by many researchers, some have historically led to the public health protection concepts [2] [7] [10] [11] [12] [27]. The ranged values for faecal coliform recorded are $8.9 \times 10^{5}-1.0 \times 10^{3}, 1.5 \times 10^{3}-2.0 \times 10^{3}, 3.5 \times 10^{3}-$ $4.5 \times 10^{3}$ and values less than $400(\mathrm{MPN} / 100 \mathrm{ml})$ for the influent, UASB reactor effluent, trickling filter effluent and the final settling tank effluent respectively. The various treatment units achieve a significant reduction in the faecal coliform 
Table 3. Summary of final effluent discharge of the previous work and this work and comparison with EPA Ghana guidelines.

\begin{tabular}{|c|c|c|c|}
\hline Parameters & Awuah \& Abrokwa (2008) & This Work & EPA guideline \\
\hline \multicolumn{4}{|c|}{ FINAL EFFLUENT } \\
\hline $\mathrm{pH}$ & $7.45 \pm 0.14$ & $8.04 \pm 0.10$ & $6-9$ \\
\hline Temperature $\left({ }^{\circ} \mathrm{C}\right)$ & - & $24.49 \pm 1.99$ & $<30$ \\
\hline Conductivity $(\mu \mathrm{S} / \mathrm{Cm})$ & - & $1383 \pm 428$ & 1500 \\
\hline Dissolved oxygen (mg/l) & $4.24 \pm 1.08$ & $1.76 \pm 0.70$ & - \\
\hline Turbidity (NTU) & $122 \pm 5 \mathrm{e} 0.27$ & $20.71 \pm 7.0$ & 75 \\
\hline Total solids (mg/l) & $958 \pm 93.78$ & $260.3 \pm 101$ & 50 \\
\hline $\mathrm{COD}(\mathrm{mg} / \mathrm{l})$ & $146 \pm 20.62$ & $129.9 \pm 53$ & 250 \\
\hline BOD (mg/l) & $23 \pm 5.74$ & $23.88 \pm 4.50$ & 50 \\
\hline Oil and grease (mg/l) & - & $0.54 \pm 0.5$ & 5 \\
\hline Colour (TCU) & - & $191.3 \pm 46$ & 200 \\
\hline Ammonia-nitrogen (mg/l) & $2.6 \pm 0.68$ & $37.73 \pm 4.14$ & 1 \\
\hline Nitrate-nitrogen (mg/l) & $22.1 \pm 0.83$ & $253.2 \pm 35$ & 50 \\
\hline $\mathrm{TKN}(\mathrm{mg} / \mathrm{l})$ & $43.1 \pm 1.15$ & & - \\
\hline Sulphate (mg/l) & - & $65.53 \pm 5.45$ & 200 \\
\hline Phosphate-phosphorus & $0.5 \pm 0.14$ & $6.71 \pm 0.63$ & 2 \\
\hline Faecal coliform MPN/100 ml) & $2.16 \times 10^{2} \pm 16.31$ & $3.78 \times 10^{2} \pm 16.31$ & 400 \\
\hline
\end{tabular}

removal contributing to the low value obtained in the final effluent. The most critical microbial load in waste water is faecal coliform counts and the resultant final load in the effluent was found to be less than $400 \mathrm{MPN} / 100 \mathrm{ml}$ as provided by the Ghana EPA guideline. The overall removal efficiency of the plant was $99.6 \%$.

\section{Conclusions}

- The overall performance of the various treatment units after renovation of the treatment plant was satisfactory.

- Almost all of the monitored physico-chemical and microbiological parameters met the Ghana EPA guidelines except ammonia-nitrogen, phosphate and suspended solids which exceeded the regulations guidelines.

- Final effluent discharge from the treatment plant into the Korle-Lagoon may not cause health risks or any environmental related problems.

- The plant performance is currently higher (after renovation) than the one reported in literature before the renovation.

- The effectiveness of the rehabilitated Mudor waste water treatment plant is a wakeup call for political will to be candled and invest in the area of sanitation especially in the rehabilitation of the existing WWTP that have not been operational for several years now in the country. 
- The efficiency of the plant is also a confidence build up in the handlers of the plant (Sewerage Systems Ghana Ltd.) capabilities to rehabilitate and operate sewage and waste water treatment plants in Ghana.

\section{Acknowledgements}

The authors would like to extend their profound gratitude to Sewerage Systems Ghana Ltd., the executive chairman (EC) of the Jospong group of companies (JGC), as well as the board and management of Sewerage Systems Ghana ltd.

\section{Competing Interest}

The authors would like to declare that, we have no significant competing financial, professional or personal interests that might have influenced the performance or presentation of the work described in this manuscript.

\section{References}

[1] Ministry of Local Government and Rural Development (2010) Environmental Sanitation Policy.

[2] Awuah, E. and Abrokwa, K.A. (2008) Performance Evaluation of the UASB Sewage treatment Plant at James Town (Mudor) Accra, Ghana. Access to Sanitation and Safe Water: Global Partnership and Local Action. 33rd WEDC International Conference, Accra, Ghana, 7-11 April 2008, 20-26.

[3] UNICEF (2016) Assessment of Waste Water Treatment Plants in Ghana.

[4] Ahmed, I., Quarshie, A.M., Ofori-Amanfo, D., Cobbold, F., Simon, E., Amofa-Sarkodie and Awuah, E. (2018) Assessment of Foreign Material Load in the Management of Faecal Sludge in the Greater Accra Region of Ghana. International Journal of Energy and Environmental Science, 3, 27-36.

[5] Hamed, M., Khalafallah, M.G. and Hassanein, E.A. (2004) Prediction of Waste Water Treatment Plant Performance Using Artificial Neural Network. Environmental Modeling and Software, 19, 919-928. https://doi.org/10.1016/j.envsoft.2003.10.005

[6] Hanbay, D., Turkoglu, I. and Demir, Y. (2008). Prediction of Wastewater Treatment Plant Performance on Wavelet Packet Decomposition and Neutral Networks. EXpert Systems with Applications, 34, 1038-1043. https://doi.org/10.1016/j.eswa.2006.10.030

[7] Belhaj, D., Jaabiri, I., Turki, N., Azri, C., Kallel, M. and Ayadi, H. (2014) Descriptive and Multivariable Analysis of the Water Parameters Quality of Sfax Sewage Treatment Plant after Rehabilitation. IOSR Journal of Computer Engineering (IOSR-JCE), 16, 81-91. https://doi.org/10.9790/0661-16178191

[8] Karikari, A.Y., Bernasko, J.K. and Bosque-Hamilton, E.K.A. (2007) An Assessment of Water Quality of Angaw River in South-Eastern Coastal Plains of Ghana. West African Journal of Applied Ecology, 11, 77-87.

[9] WHO (2004) Guidelines for Drinking-Water Quality. Vol. 1, 3rd Edition, World Health Organization, Geneva.

[10] WHO (2004) Water, Sanitation and Hygyiene Links to Health: Facts and Figures. WHO, Geneva. http://www.WHO.int/water_sanitation_health/publications/facts2004/en/

[11] Gao, H.W., Lin, J., Li, W.H., Hu, Z.J. and Zhang, Y.L. (2010) Formation of Shaped 
Barium Sulphate-Dye Hybrids: Waste Dye Utilization for Eco-Friendly Treatment of Wastewater. Environmental Science and Pollution Research, 17, 78-78. https://doi.org/10.1007/s11356-009-0249-7

[12] Kolpin, D.W., Skopec, M., Meyer, M.T., Furlong, E.T. and Zaugg, S.D. (2004) Urban Contribution of Pharmaceuticals and Other Organic Wastewater Contaminants to Streams during Differing Flow Conditions. Science of the Total Environment, 328, 119-130. https://doi.org/10.1016/j.scitotenv.2004.01.015

[13] Snyder, S.A., Villeneuve, D.L., Snyder, E.M. and Giessy, J.P. (2001) Identification and Quantification of Estrogen Receptor Agonists in Wastewater Effluents. Environmental Science \& Technology, 35, 3620-3625. https://doi.org/10.1021/es001254n

[14] Dione, I. (2002) Expériences de l'ONAS dans le choix et la gestion des stations de lagunage au Sénégal, séminaire CEREVE-EIER Traitement des eauxusées par lagunage: Challenges et perspectives pour les pays envoie de développement. 4 November 2002, Ouagadougou.

[15] APHA, AWWA, WEF (2012) Standard Methods for the Examination of Water and Wastewater. 22nd Edition, Washington DC.

[16] Princic, A., Mahne, I., Megusar, F., Paul, E.A. and Tiedje, J.M. (1998) Effects of the $\mathrm{pH}$ and Oxygen and Ammonium Concentrations on the Community Structure of Nitrifying Bacteria from Wastewater. Applied and Environmental Microbiology, 64, 3584-3590.

[17] El-Taweel, G.E., Shaban, A.M., El-Hawaary, S. and El-Gohary, F.A. (2002) Microbiological Characteristics of Wastewater in Egypt: II-Treated Effluent. Egyptian Journal of Microbiology, 35, 239-256.

[18] UNEP (2008) Water Quality for Ecosystem and Human Health. 2nd Edition, UNEP ERCE, Nairobi.

[19] Usharani, K., Umarani, K., Ayyasamy, P.M., Shanthi, K. and Lakshmanaperumalsamy, P. (2010) Physico-Chemical and Bacteriological Characteristics of Noyyal River and Ground Water Quality of Perur, India. Journal of Applied Sciences and Environmental Management, 14, 29-35. https://doi.org/10.4314/jasem.v14i2.57830

[20] Deas, M.L. and Lowney, C.L. (2000) Water Temperature Modelling Review. California Water Modelling Forum, Central Valley, California.

[21] Alabaster, J.S. and Lloyd, R. (1980) Water Quality Criteria of Freshwater Fish. Butter Worth, London-Boston.

[22] Oluyemi, E.A., Adekunle, A.S., Adenuga, A.A. and Makinde, W.O. (2010) Physico-Chemical Properties and Heavy Metal Content of Water Sources in Ife North Local Government Area of Osun State, Nigeria. African Journal of Environmental Science and Technology, 4, 691-697.

[23] Nthumbi, R.M., Ngila, J.C., Moodley, B., Kindness, A. and Petrik, L. (2012) Application of Chitosan/Polyacrylamide Nanofibres for Removal of Chromate and Phosphate in Water. Physics and Chemistry of the Earth, 50-52, 243.

[24] Akoto, O., Bruce, T.N. and Darko, G. (2010) Chemical and Biological Characteristics of Streams in the Owabi Watershed. Environmental Monitoring and Assessment, 161, 413-422. https://doi.org/10.1007/s10661-009-0757-4

[25] Akpabli, C.K. and Drah, G.K. (2001) Water Quality of the Main Tributaries of the Densu Stream. Journal of Geovisualization and Spatial Analysis, 3, 84-89.

[26] Akoto, O., Gyamfi, O., Darko, G. and Barnes, V.R. (2014) Changes in Water Quality in the Owabi Water Treatment Plant in Ghana. Applied Water Science, 7, 175-186.

[27] Garcia-Armisen, T. and Servais, P. (2006) Respective Contribution of Point and 
Non-Point Sources of E. coli and Enterococci in Large Urbanized Watershed (The Seine River, France). Journal of Environmental Management, 82, 512-518.

https://doi.org/10.1016/j.jenvman.2006.01.011 